\title{
Experiments on the Development of the Nuptial Coloration and Pearl organs of the Japanese Bitterling.
}

\author{
By \\ Tomizyu Tozawa. \\ Biological Laboratory, Keio Medical College. \\ With 9 text figures and 1 plate (XXXII). \\ Experimental studies on the nuptial coloration of fishes have been
} made by Kopec('18), Titschack('22), van Oordt('24), Bock('27), et al. At the suggestion of Professor N. Yatsu the writer undertook a similar study on the Japanese Bitterling, Acheilognathus intermedium Temminck et Schlegel.

\section{Observations.}

Secondary Sexual characters: To the inexperienced observer it is very difficult to distinguish the sexes of Acheilognathus intermedium from the outside. A few words on certain external features which serve as sexual characteristics may therefore be of some value to those who use this fish as laboratory animals.

The male is more elongated and slightly larger than the female. The female is plump, especially in the abdominal region during the breeding season. In general the anterior half of the body is larger than the posterior in the male, but the opposite is usually true of the female. All the fins of the male are larger than those of the female; especially the dorsal, anal, and caudal fins. The forms of dorsal and anal fins in the male are both almost equilaterally triangular, while those of the female are rather elongated. The two tips of the tail fin are pointed in the male and rather rounded in the female. The forms of the 
pectoral and the pelvic fins in the male are elongated, narrowing towards the end, while those of the female are broad and somewhat shorter. An elongated fold of skin is present in front of the anus in the female and a long ovipositor protrudes from this during the breed-

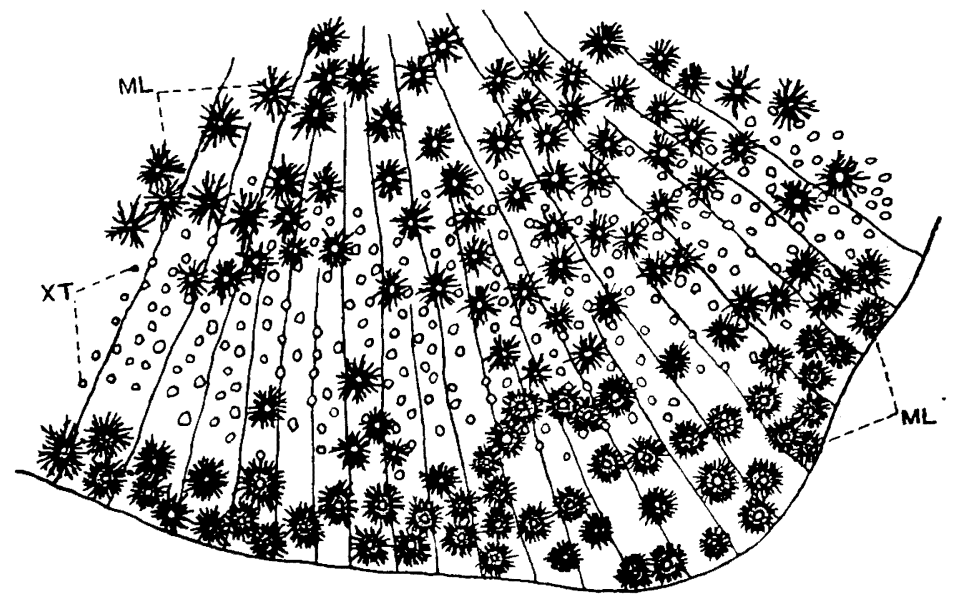

Fig. 1 .

Chromatophores from portion of fresh scale; from dorsum of male fish from border of dark area. $\times 40$. III, melanophores; XI, xanthophores.

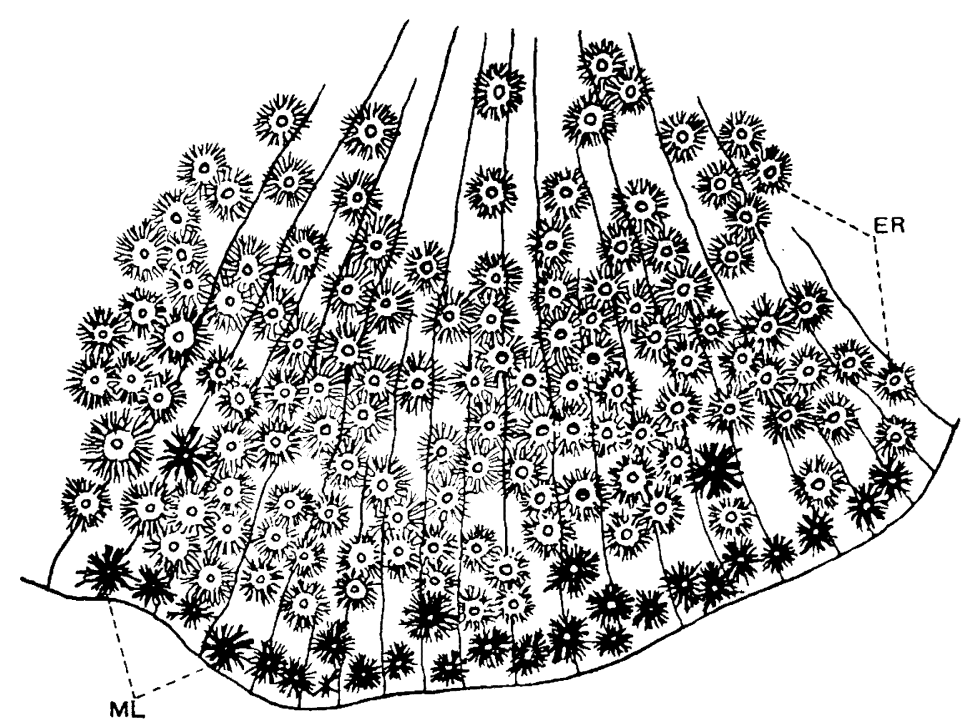

Fig. 2.

Chromatophores from portion of fresh scale: from lateral region of male fish from borler of red area. $\times 40$. iI $\mathrm{S}$, melanopmores; $\mathrm{FR}$, errthrophores. 
Experiments on the Development of the Nuptial Coloration and Pearl organs ete. 409

ing season. The pearl organs are found on the anterior end of the head in the male, but are absent from the female.

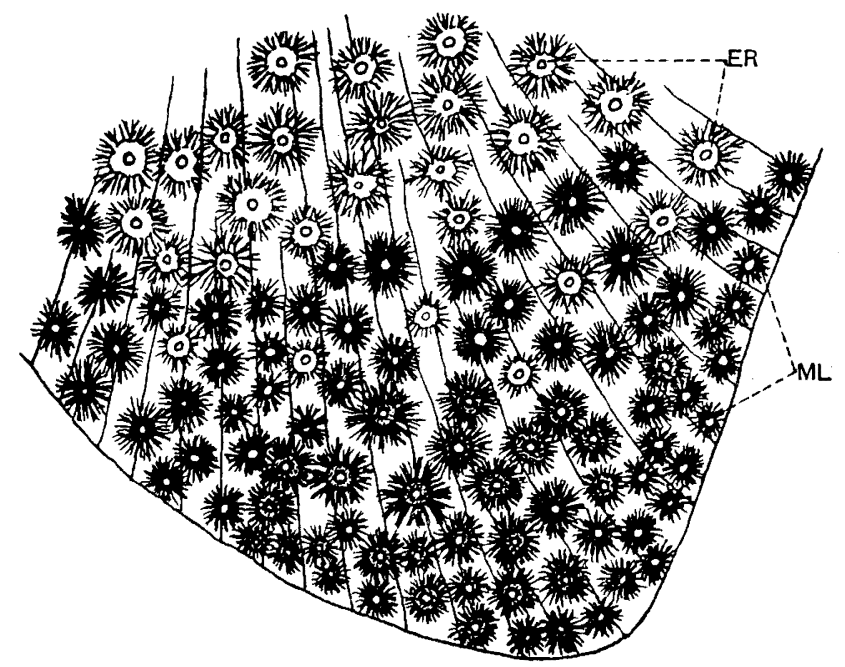

Fig. 3.

Chromatophores from portion of fresh seale; from ventrum of male fish from border of dark area. $\times 40$. II I, melanophores; ER, erythrophores.

Nuptical colorations: The nuptical coloration varies with the sex. It is generally less apparent in the female, in which small portions of

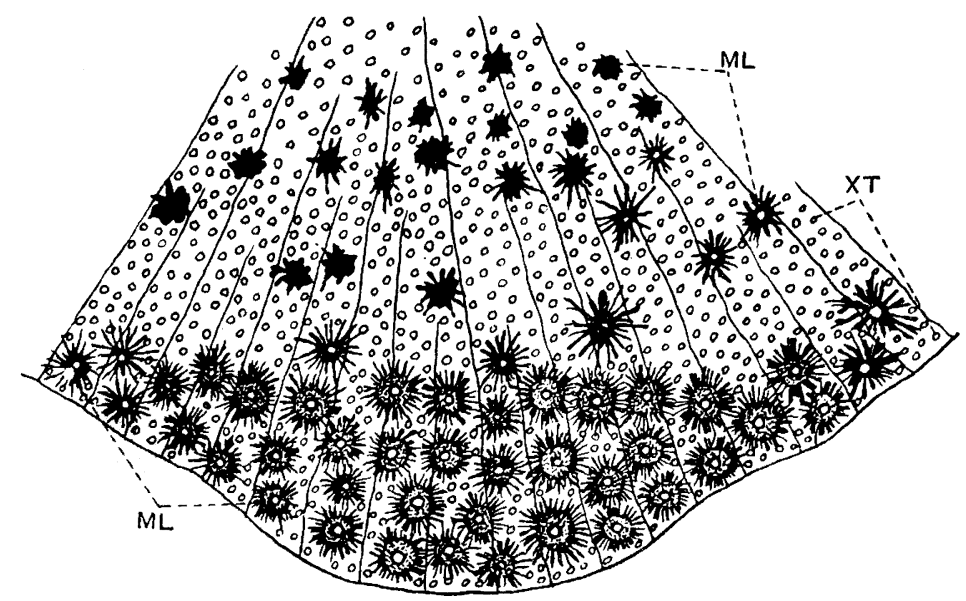

Fig. 4.

Chromatophores from portion of fresh scale; from dorsum of female fish from border of dark area. $\times 40$, II L, melanophores; XT, xanthophores. 


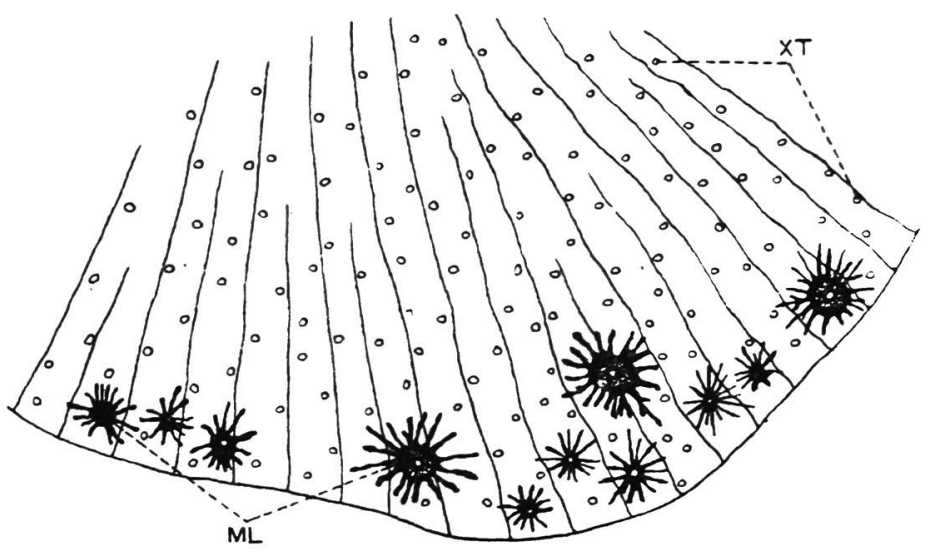

Fig. 5.

Chromatophores from portion of fresh scale; from ventrum of female fish from border of light area. $\times 40$. II $\mathrm{L}$, melanophores; $\mathrm{X} T$, xanthophores.

the dorsal and aual fins may become pinkish, but the general body color undergoes no marked change. The male fishes, on the contrary, develop black coloring all over the body, especially on the pelvic fins and on the ventro-medial portion of the body. As will be seen in Plate XXXII a bright red color appears on the head, operculum, anterio-lateral regions, tail, and on considerable portions of the dorsal and anal fins. The iris also becomes reddish and the posterior half of the body becomes somewhat bluish.

Appearance and $\mathrm{Dis}$ appearance of Colors: The breeding season of Acheilognathus inter-

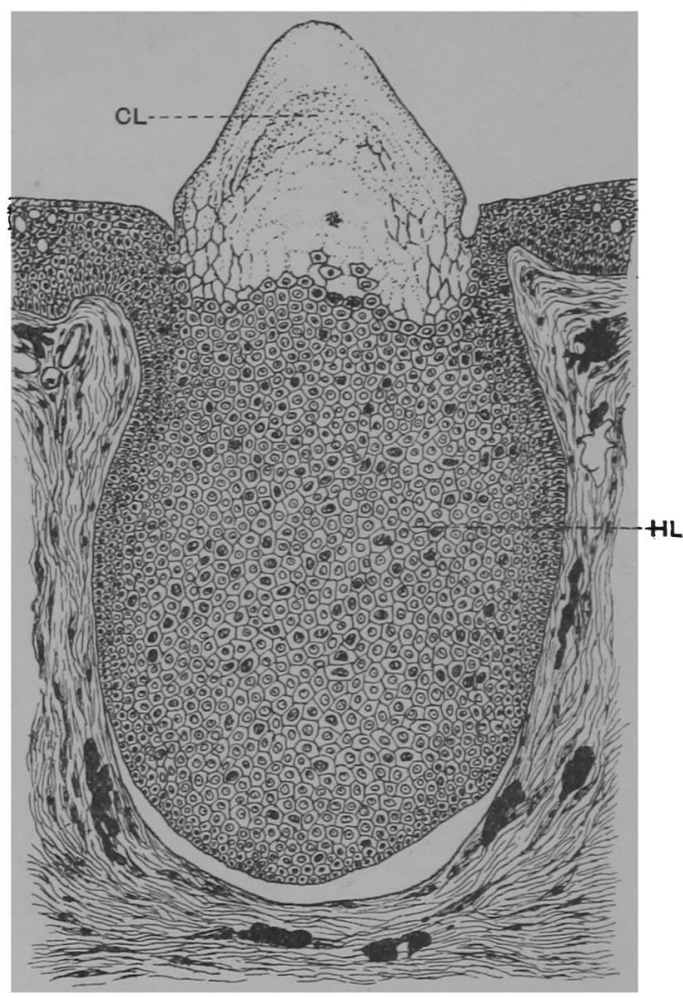

Fig. 6 .

Section through pearl organ. $\times 200$. CI, cornified epidermal layer; H I, hspertrophied epidermal lajer. 
Experiments on the Development of the Nuptial Coloration and Pearl organs etc. 411

medium extends in a gencral way from spring to the begiming of summer. In or near Tokyo the nuptical color appears in the latter part

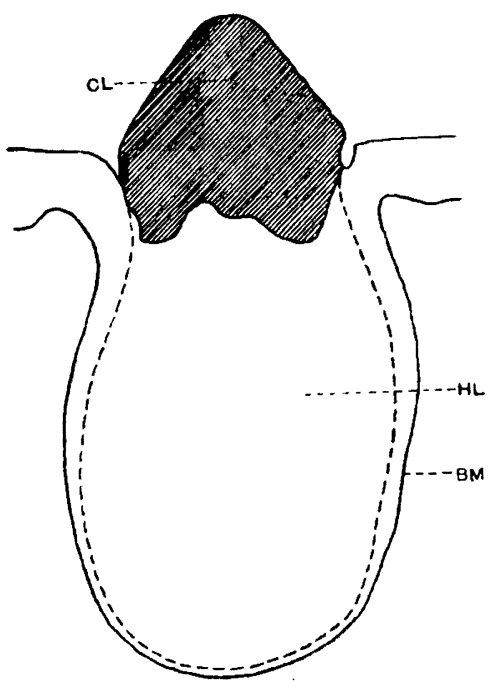

Fig. 7.

Diagram of a pearl organ from the head of Acheilognathus inter. medium. $\times 150$. CL, cornified epidermal laver; $\mathrm{HI}$, hypertrophied epidermal layer; BM, basal membrane.

one maximum. It may be recalled that the pearl organs in the goldfish have 3 to 6 maxima.

The relation between nuptial coloration and various chromatopheres in the epithelial tissues may be mentioned here. As in most fishes there are four different kinds, viz., melanophores, erythrophores, ${ }^{1)} \quad$ xanthophoras, and guanophores. These four kinds do not coexist in the same region excepting in regions where one color passes over to another. of March and may be seen until the middle of June. During the period extending from April 20 to May 10 it attains the highest development so far as the writer's obser- vations go.

Nuptial coloration disappears gradually. The red on the head, operculum, and anterio-lateral regions fades first and the black on all parts of the body goes very slowly. The time of the appearance of the nuptial coloration varies a great deal. The total period during which it is present varies from 30 to 70 days. But in each individual it develops rather rapidly and reaches its height (5-10 days) in 8 to 10 days. From the curves the writer plotted daily from observations on the nuptial color of each fish, taking degree of color development as ordinates and number of days as absissae, it was found that there is only

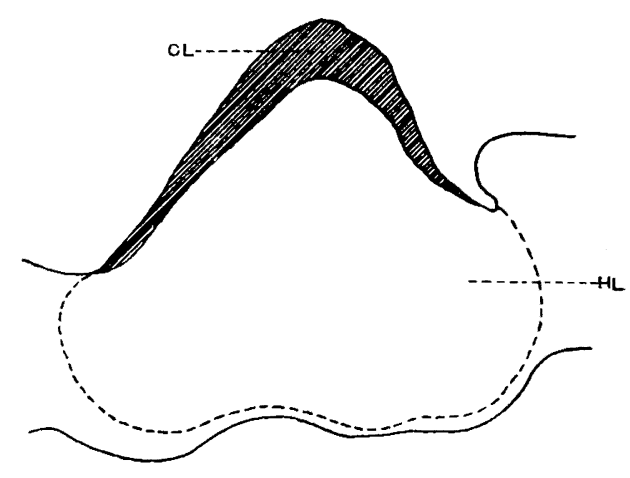

Fig. 8 .

Diagram of a pearl organ from the pectoral fin of the goldfish. $\times 150, \mathrm{CI}_{2}$, cornfied epidermal layer; $\mathrm{HL}_{\mathrm{L}}$, hypertrophied epidermal layer.

1) Erythrophores do not exist in the female except on the dorsal aud anal fins. 


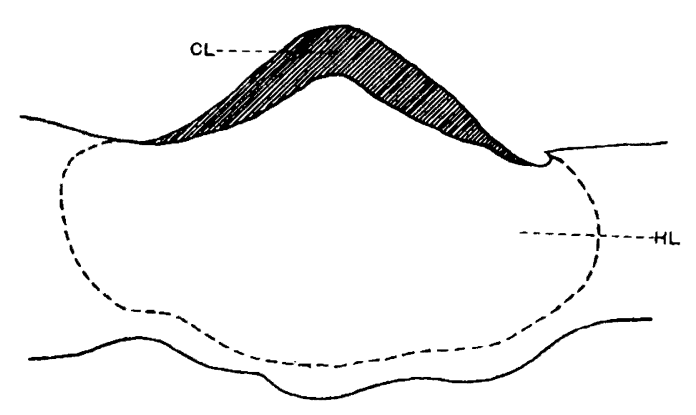

Fig. 9.

Diagram of a pearl organ from the operculum of the goldfish. $\times 150$. Cl, cornified epidermal layer; HI, hypertrophied epidermal layer.

The results are shown in Table 1 .
Usually the melanophores form the outernost layer, and under them lie the erythrophores, xanthophores and guanophores in order. These chromatophores are not situated one upon the other but rather take a mosaic as seen from the surface. ${ }^{1)}$ Scales were plucked out from different regions of the body and the erythrophores and melanophores on them were counted.

Table 1.

Numbers of chromatophores on separate scales.

\begin{tabular}{|c|c|c|c|}
\hline & \multicolumn{2}{|c|}{ Melanophores } & Erythrophores \\
\hline \multirow{2}{*}{ Dorsum } & Ventrum & Iateral surfaces \\
\hline 0 & $125-201$ & $85-110$ & $127-185$ \\
\hline $66-89$ & $5-11$ & 0 \\
\hline
\end{tabular}

Nuptical coloration is brought about by the change in size and shape, but not in the number, of chromatophores. Both the melanophores and erythrophores expand most at the height of the development of coloration (Figs. 1-5). At the time of disappearance of the nuptial coloration all the erythrophores and most, if not all, of the melanophores are found in the maximum state of contraction.

Pearl organs: The pearl organs found in many cyprinoid fishes during the breeding season have been studied by von Siebold('63), Leydig('64, '79, '92, '95), Selger('78, '79), Reighard('04, '10), Maurer('15), Innes('17), Smith('17), Meisenheimer('21), Tozawa ('23). So far as the writer knows, no work has previously been done

1) These special arrangements are significants not only for the economy of color, but for the centrifugal and centripetal transformations of the chromatopbores. 
on the pearl organs of Acheilognathus intermedium. In this spccies they are found only at the tip of the head just anterior to the nostril, and number from five to ten. To the naked eye they appear as small white warts arranged in a round group. With a hand lens one can readily detect that they are conical elevations of the epidermis. They are all of almost the same size, and thus differ from those of the goldfish. They reach $125 \mu$ in diameter and 100 to $125 \mu$ in height. They appear in the latter part of March and may be seen until the middle of June. They grow rapidly to their maximum size, but are reduced very slowly and finally disappear entirely before the fading away of the nuptial coloration. They are present for from 30 to 50 days and develop only once each year.

For histological study materials were fixed with acetic-sublimate and embeded either in paraffin or in celloidin. Sections were stained with Delafield's haematoxylin and eosin. Sometimes borax-carmine with a counter stain of picric acid was used to advantage. The ordinary epidermis consists of some fifteen layers of cells, and measur 25 to $40 \mu$ in thickness. Most parts of the epidermis are composed of flattened cells, but three or four cell layers above the basal membrane the cells are elongated, the basal cells being the longest.

In a section through a portion of epidermis which bears pearl organs, one notices that here the cell-layers thicken a great deal and form an external protuberance but also bulges down into the dermis. The epidermal thickening is due largely to the hypertrophy of the epidermal cells, as has been described in the goldfish (Tozawa, 1923). Each cell is nearly twice the diameter of an ordinary epidermal cell and is provided with a vesicular nucleus, which also surpasses in size those of unmodified cells. The cytoplasm of the hypertrophied cells takes a lighter stain than in other parts of the epidermis. The number of cell layers increases to 51 to 63 . Below the hypertrophied area the basal cells are not cylindrical, but are compressed and resemble the upper cells of the ordinary epidermis in shape. The lateral margin of the hypertrophied area blends into the unmodified epidermis (Fig. 6). The hypertrophied area appears in sections to be vertically elongated in Acheilognathus intermedium, while in the goldfish this is horizontally elongated as will be seen from the accompanying sketches (Figs. $2,3,4)$. Nitotic figures are present both in the modified area and in the ordinary epidermal cells near the lateral margin of the area. From this it is evident that new cells are added not only in the modified region but also about its the periphery. 
Over the hypertrophied area is a cornified cap, the pearl organ. It is 100 to $125 \mu$ in thickness and $125 \mu$ in diameter. It takes a strong plasmastain in sharp contrast to the underlying cells. Its component cells are scaly and cornified. They are provided with pycnotic nuclei, or sometimes lack nuclei altogether. It is interesting to note that sometimes the inmermost cells adjacent to the hypertrophied cells are provided with vesicular nuclei, whereas their cytoplasm stains exactly like that of cornified cells. The cornified cap in this species is more prominent and thicker than in the goldfish, as will be seen from the accompanying sketches (Figs. 7, 8, 9). After some time the cornified cap is shed gradually from the surface, leaving behind a core of hypertrophied cells. The uppermost cells of hypertrophied area cornify successively. supplying new caps. On the whole, the modified epidermal area with a pearl organ on the top has a very strong resemblance to the thickenings on thumbs of male salientians.

\section{Experiments.}

In order to determine whether or not the appearance of the nuptial coloration of Acheilognathus intermedium is under the influence of the sex glands, the writer performed some castrations and ovariotomies at four different times. The operation is rather difficult on account the small size of the fishes. One has to pull off a few scales on one side of the body and then make an incision. The sex glands are taken out by means of a pair of forceps with bent points. A suture is made with a piece of silk thread. Collodion is applied over the incision. Throughout the operation both the head and tail are covered with a piece of wet cloth so as to keep the fish quiet. A large percentage of the fishes thus operated upon continued to be healthy but some died from growths of Saprolegnia. In such cases a weak solution of sodium permanganate was applied and sometimes saved them from death.

Experiment 1: Operation were performed upon 30 males and 26 females between March 5 and 7 , before the breeding season and long before the appearance of the nuptial coloration. Of these 14 were totally and 16 partially (unilaterally) castrated; 12 were totally and 14 partially ovariotomized. It was found that at this time neither the testes nor the ovaries had yet attained their full growth.

When examined on May 31 totally castrated fishes showed no pearl organs or nuptial coloration. In partially castrated fishes no pearl organs developed, but $50 \%$ of them showed nuptial coloration such as appeared 
Experiments on the Development of the Nuptial Coloration and Pearl organs etc. 415

in all the controls. At the same time totally ovariotomized fishes showed neither the nuptial coloration nor the ovipositor. $43 \%$ of partially ovariotomized females had the nuptial coloration, and $29 \%$ had the ovipositor extended. All the control fishes showed nuptial coloration and the ovipositor. It is clear from this experiment that the appearance of the nuptial coloration was retarded or suppressed by the operations until as late as May 31. In normal fishes the nuptial coloration usually makes its appearance at the latest at the end of April.

Experim ent 2: Operations were performed at the begimning of the breeding season, between April 4 and 6, upon 18 males and 17 females. All of the individuals had no nuptial coloration. 6 were totally castrated, 12 had the testis on one removed; 7 were totally ovariotomized, 10 had the ovary on one side removed. All were examined on May 31. The totally castrated fishes had no pearl organs at all, but the nuptial coloration developed in $50 \%$ of them. The partially castrated fishes also had no pearl organs at all, but the nuptial color developed in 58\%. All the controls had both pearl organs and nuptial coloration. $57 \%$ of totally ovariotomized fishes had the nuptial coloration, but no protruding ovipositor. $70 \%$ of partially ovariotomized ones acquired the nuptial color and the extended ovipositor.

Experiment 3: Operation were performed in the middle of the breeding season when some fishes already had nuptial coloration. The fishes operated on were those which showed least red colorations. Gonadectomy was performed between May 4 and 5 on 14 males and 12 females. Of these 5 were totally castrated, 9 partially castrated ; 5 were totally ovariotomized; 7 partially ovariotomized. All were examined on May 31. Most of the totally castrated fishes had no pearl organs, the nuptial coloration developed in $80 \%$. Only $22 \%$ of the partially castrated fishes had the pearl organs, but the nuptial coloration developed in $89 \%$. $60 \%$ of totally ovariotomized fishes had the nuptial coloration, but no ovipositor. $86 \%$ of partially ovariotomized females had the nuptial coloration and the extended ovipositor.

From these experiments it may be seen that the appearance of nuptial coloration and pearl organs is somewhat inhibited in the partially gonadectomied individuals and still more so in the totally gonadectomied group.

Experiment 4: Operation were performed on April 25 when the nuptial color was at the height of its development. 6 males were totally castrated and 6 partially castrated. The time of disappearance of the nuptial coloration was determined. In the totally castrated individuals 
it lasted from 22 to 25 days, in the partially castrated group from 34 to 36 days, and in controls from 50 to 53 days. This shows clearly that the lack of testes quickens the disappearing of the nuptial coloration.

From the foregoing series of experiments there is good reason to believe that the appearance of the nuptial coloration during the breeding season is greatly influenced by the internal secretions produced by the sex glands. The absence or decrease of these substances totally or partially suppresses the nuptial coloration. In this connection it is worth while to mention that the results of castration experiments on sticklebacks performed by F. Bock coloration agree fairly well with those of the writer in regard to the effects on nuptial coloration.

\section{Summary.}

1. Gonadectomy was performed at various periods on the Japanese Bitterling, Acheilognathus intermedium, to see the relation between nuptial coloration and pearl organs and the sex glands.

2. The male fishes during the breeding season acquire black coloration on the body and red on the head, operculum, anterio-lateral surfaces.

3. In the females the uuptial color is less apparent. Pink appears only on the dorsal and anal fins.

4. Nuptial coloration lasts for 30 to 70 days. In 8 to 10 days it reaches its maximum development is at its height for from 5 to 10 days, and fades away very slowly.

5. Melanophores differ in number with sex. Erythrophores are not found in the female, except on the dorsal and anal fins.

6. If gonadectomy was performed before the appearance of nuptial coloration, its appearance was retorded. If the operation were done during the breeding season, in most of the fishes the nuptial color appeared in spite of the operation. If the fishes are gonadectomied during the period of highest development of the nuptial coloration, it disappeared earlier than in unoperated fishes.

7. Pearl organs are found as a small group only at the tip of the head immediately anterior to the nostril. They appear in the breeding scason and disappear earlier than the nuptial coloration. They appear only once each year.

8. Gonadectomy retards or inhibits the appearance of the pearl organs.

9. The appearance of the nuptial coloration and the formation of 
Experiments on the Development of the Nuptial Coloration and Pearl organs etc. 417

the pearl organs are influenced by a substance or substances produced by the sex glands.

(June 3rd, 1929).

\section{Literature.}

Bock, F. '27. Kastration und sekundäre Geschlechtsmerkmale bei Teleostiern : Zeitschrift für wissensch. Zoologie, Bd. 130, Heft. 3/4.

Kopec, s. '18. Contribution to the study of the development of the nuptial color of fishes: C. R. de la Soc. des Sc. de Varsovie, XI Annee, Fasc. I.

Titschack, F. '22. Die sekundären Geschlechtsmerkmale von Gasterosteus acu leatus I.: Zool. Jahr., Abt. f. Allg. Zool. u. Phys., Bd. 39.

Tozawa. T. '23. Studies on the pearl organ of the Goldfish: Amnot. Zool. Japon., Vol. 10.

Van Oordt, G. J. '2-t. Die Veränderungen des Hodens während des Auftretens der sekundären Geschlechtsmerkmale bei Fischen: Arch. f. mikrosk. Anat. u. Ent.-Mech., Bd. CII.

\section{Explanation of Figures (Plate XXXII).}

1. Normal female in full nuptial dress; natural size.

2. Completely ovariotomized female.

3. Normal male in full nuptial dress; natural size.

4. Individual completely castrated at the highest development of the nuptial color.

5. Incompletely castrated male.

6. Completely castrated male. 
FOLIA ANATOMICA JAPONICA, BD. VII.

TAF. XXXII.

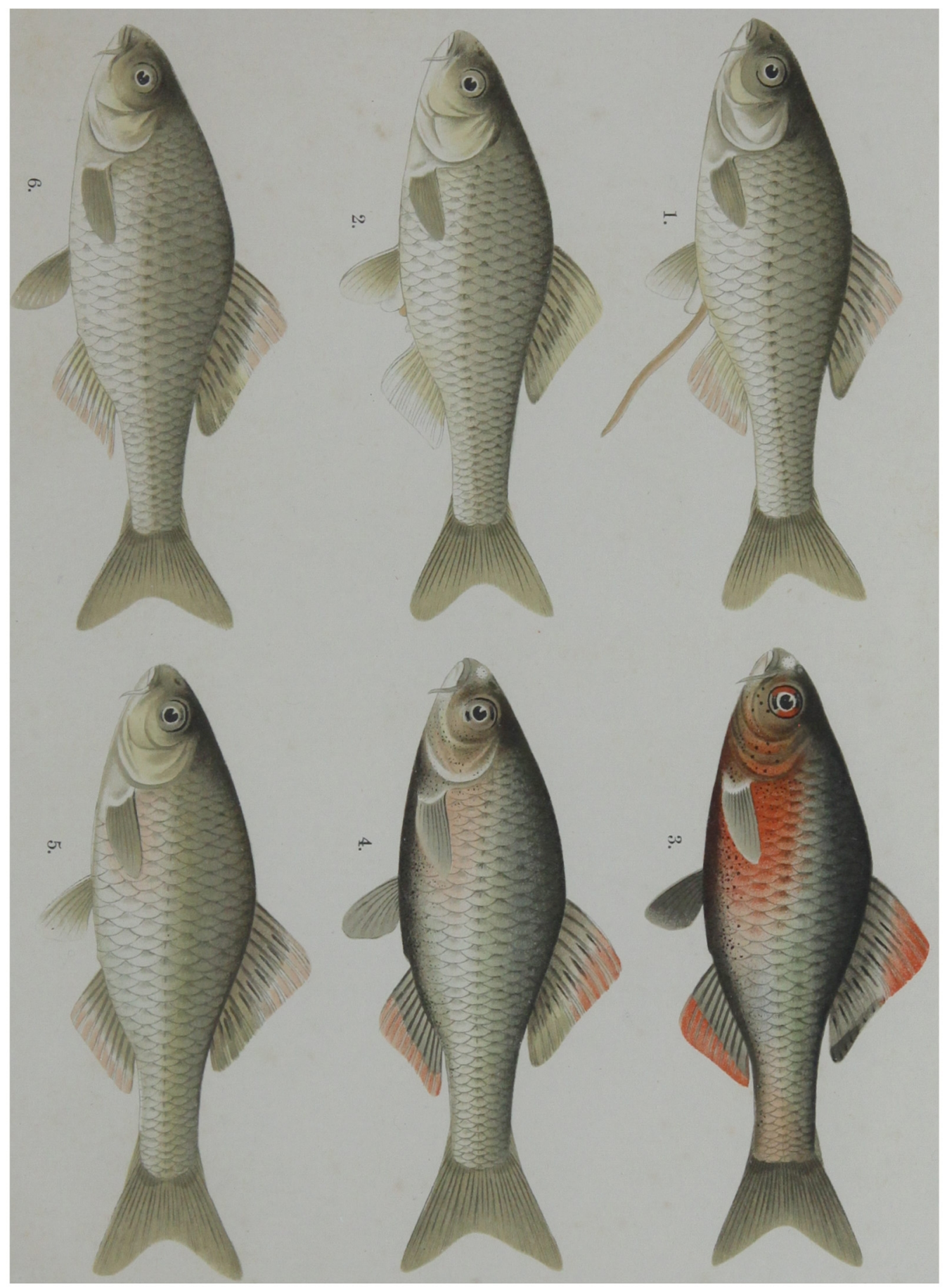

T. Tozawa. 